\title{
Aggregate Impact of the Country in Concrete Durability, that Works in Normal Environmental Conditions
}

\author{
Dr. Ing. Alma Golgota \\ Engineering Science Dept, University of “ A. Moisiu”,,Durres,Albania \\ almagolgota@uamd.edu.al, almagolgota@yahoo.com
}

Mrs. Ark. BorianaVrusho

PhD Cand. Epoka University of Tirana, Albania

\begin{abstract}
Production and use of durable concrete in reinforced concrete structures is a necessity in our country. In this article it was treated as affecting the characteristics of aggregates in durable concrete production, when they work in normal environmental conditions. To achieve this goal have produced concrete of class C35 / 45 with aggregate taken in careers mountain and river. The other components are the same in mix design concrete. Water-cement ratio is 0.5 and $0: 35$ realized. Comparisons are made of the resistance to compression and water penetration. Cubes of concrete had been produced and treated in terms shipyard. There have been comparisons of results and following. Today in Durres, even wider, buildings constructed with durable concrete are very few in now days. Geological studies show that the soil in foundation has low retaining capacity for this city due to high friction angle. This is also one of the other factors that Seismicity of the area is very high, up to level 9 ball of Rihter. The purpose of this article is the production of durable concrete with low permeability of water. The project is constructed in our country and in particular in Durres where groundwater level is higher and the use of space efficiently needs to build parking with underground floor.
\end{abstract}

Keywords: Concrete durability, aggregate, permeability of durable concrete, strength concrete

\section{INTRODUCTION}

With the use of concrete durability we go further and ask that concrete have much longer life not only to the destruction but their work time or as called "lifetime" or the time before the repair, be much longer. This requires that we seek concrete durability and longevity of the structure reinforced concrete. For this purpose we must consider:

1. To obtain concrete durability in use should distinguish between possible life of concrete as a material to be used in specific environmental conditions and longevity of concrete factual deed therefore be taken into account that concrete properties in the composition of the structure.

2. The water impermeable concrete with a resistance to water penetration under ISO 7031-1994 standard specifications, or otherwise rely on standard EN 206-1, permeability should be up to 20 to $50 \mathrm{~mm}$.

\section{MATERIALS AND METHODOLOGY}

Concrete components produced by Albanian standards S EN 206-1: 2003, with resistance class C35 / 45, taken in Fushe Kruje by concrete and Shkodra Vega by Mat River to Dry Stream

\section{$2.1 \quad$ Materials}

\subsubsection{Cement}

The details of the experimental program have been reported in this study. Concrete ingredients produced by the Albanian standard S SH EN 206-1:2003, with resistance class C35/45, were taken in Fushe Kruja from Vega concrete production 
site. The concrete is produced in SAG concrete plant. Composition of Portland cement, CEM I 42.5 R, from ANTEA, type cement conforming EN 197-1 was used in this study.

Table 2.1.1: Chemical Composition of CEM I 42.5 R TITAN cement

\begin{tabular}{|l|l|l|l|l|}
\hline No. & Chemical composition & Units & Test results & $\begin{array}{l}\text { Standard limit based on } \\
\text { EN 197-1 standard }\end{array}$ \\
\hline 1 & $\mathrm{SiO}_{2}$ (Min.) & $\%$ & 18.01 & - \\
\hline 2 & $\mathrm{Fe}_{2} \mathrm{O}_{3}$ (Min.) & $\%$ & 2.69 & - \\
\hline 3 & $\mathrm{Al}_{2} \mathrm{O}_{3}$ (Min.) & $\%$ & 4.58 & - \\
\hline 4 & $\mathrm{MgO}$ (Max.) & $\%$ & 1.80 & $5.00 \%$ \\
\hline 5 & $\mathrm{CaO}$ (Min.) & $\%$ & 61.23 & $10.00 \%$ \\
\hline 6 & $\mathrm{SO}_{3}$ (Max.) & $\%$ & 2.67 & $3.50 \%$ \\
\hline 7 & $(\mathrm{Cl})$ (Max.) & $\%$ & - & $0.10 \%$ \\
\hline 8 & $\mathrm{I}$ (Max.) & $\%$ & 0.3 & $5.00 \%$ \\
\hline
\end{tabular}

Table 2.1.2: Physical Properties of CEM I 42.5 R TITAN Cement

\begin{tabular}{|l|l|l|l|l|}
\hline No. & Physical characteristics & Units & Test results & EN 197-1 Standard limit \\
\hline 1 & Specific surface, Blaine & $\mathrm{cm}^{2} / \mathrm{g}$ & 3842 & \pm 200 \\
\hline 2 & Specific density & $\mathrm{g} / \mathrm{cm}^{3}$ & - & \pm 50 \\
\hline 3 & Standard consistency & $\%$ & 28 & - \\
\hline 4 & Initial setting time & $\mathrm{min}$ & $2 \mathrm{~h}: 30 \mathrm{~min}$ & 60 \\
\hline 5 & Final setting time & $\mathrm{min}$ & - & - \\
\hline 6 & Loss on ignition (L.O.I) & $\%$ & - & $\leq 5 \%$ \\
\hline 7 & Expansion & $\mathrm{mm}$ & 0 & $\leq 10 \mathrm{~mm}$ \\
\hline
\end{tabular}

Table 2.1.3: Mechanical Properties of CEM I 42.5 R TITAN Cement

\begin{tabular}{|l|l|l|l|l|l|}
\hline \multirow{2}{*}{ No. } & \multirow{2}{*}{ Mechanical characteristics } & \multirow{4}{*}{ Units } & \multicolumn{3}{|l|}{ Test results } \\
\cline { 4 - 7 } & & & 2 Days & 28 Days & EN 197-1Standard limits \\
\hline 1 & Compressive strength & $\mathrm{MPa}$ & 26 & 48 & $\begin{array}{l}2 \text { Days }>20 \mathrm{MPa} \quad 28 \text { Days } \geq \\
42.5 \text { dhe } \leq 62.5 \mathrm{MPa}\end{array}$ \\
\hline 2 & Flexural strength & $\mathrm{MPa}$ & & & \\
\hline
\end{tabular}

\subsubsection{Aggregates}

Coarse and fine aggregates obtained from Mat river Perroi $\mathrm{i}$ Thate and Fushe Kruja quarry units have been used for this study. Maximum size of coarse aggregate used is $25 \mathrm{~mm}$ and specific gravity of ranging from $2.6-2.7 \mathrm{~kg} / \mathrm{m} 3 \mathrm{based}$ on standard S SH 509:1987; bulk density $1484 \mathrm{~kg} / \mathrm{m} 3$ and fine modulus 6.07 . For fine aggregates maximum size used is 5 $\mathrm{mm}$ and specific gravity of ranging from $2.687 \mathrm{~kg} / \mathrm{m} 3$ based on standard S SH 509:1987; and fine modulus 2.74 . 


\begin{tabular}{|c|c|c|c}
\hline sitat mm & peshat $\mathrm{g}$ & mbetjet $\%$ & kalimi \% \\
\hline 31.5 & 0.0 & 0.00 & 100.00 \\
25.0 & 0.0 & 0.00 & 100.00 \\
16.0 & 0.0 & 0.00 & 100.00 \\
12.5 & 0.0 & 0.00 & 100.00 \\
8.0 & 0.0 & 0.00 & 100.00 \\
4.0 & 10.3 & 0.70 & 99.30 \\
2.0 & 391.2 & 26.70 & 73.30 \\
1.00 & 867.3 & 59.20 & 40.80 \\
0.50 & 1082.6 & 73.90 & 26.10 \\
0.250 & 1201.3 & 82.00 & 18.00 \\
0.125 & 1278.9 & 87.30 & 12.70 \\
0.075 & 1322.9 & 90.30 & 9.70 \\
\hline
\end{tabular}

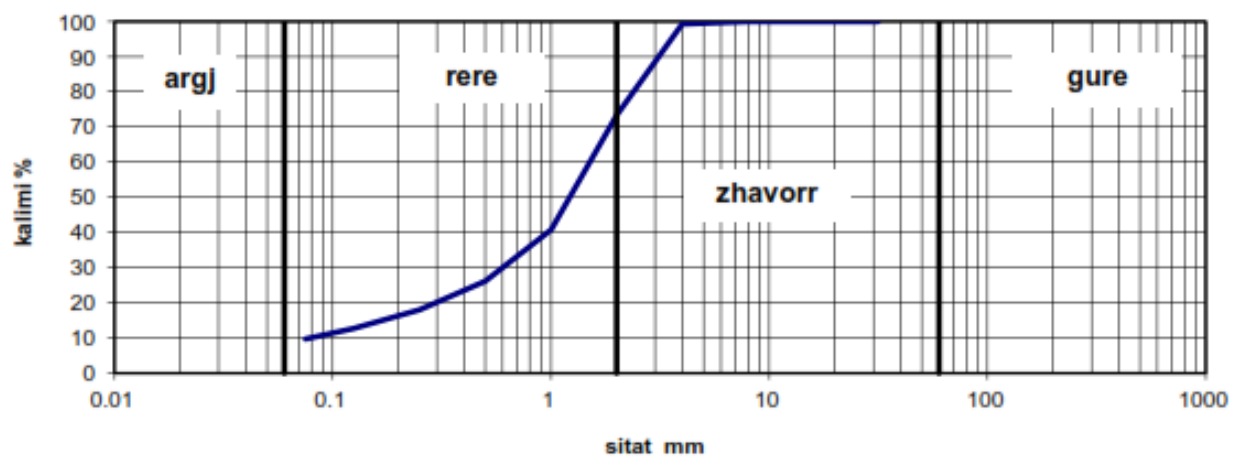

Figure 1: a) Coarse and b) fine aggregates PSD analysis river . 


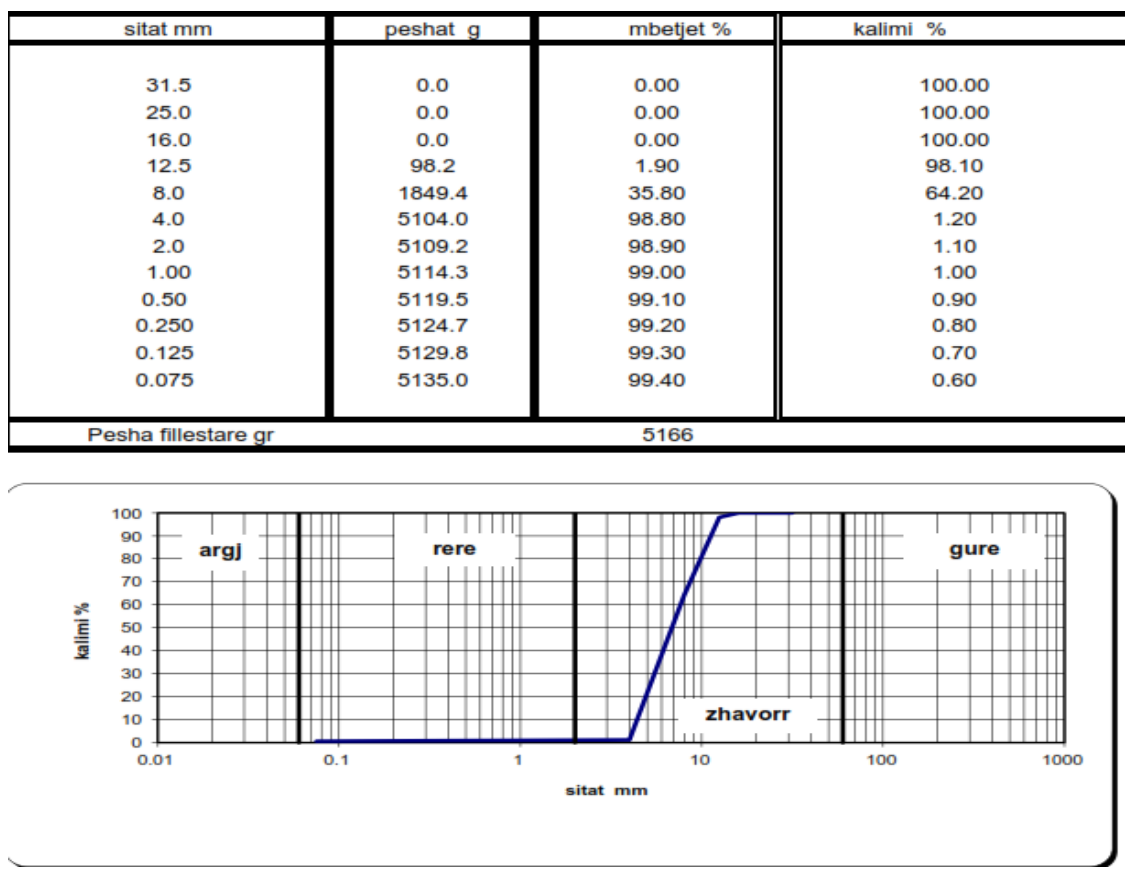

Figure 2: a) Coarse and b) fine aggregates PSD analysis river

\begin{tabular}{|c|c|c||c}
\hline sitat mm & peshat $\mathrm{g}$ & mbetjet \% & kalimi \% \\
\hline 31.5 & 0.0 & 0.00 & 100.00 \\
25.0 & 0.0 & 0.00 & 100.00 \\
16.0 & 0.0 & 0.00 & 100.00 \\
12.5 & 3278.8 & 39.70 & 60.30 \\
8.0 & 7234.9 & 87.60 & 12.40 \\
4.0 & 8217.7 & 99.50 & 0.50 \\
2.0 & 8242.5 & 99.80 & 0.20 \\
1.00 & 8244.1 & 99.82 & 0.18 \\
0.50 & 8246.6 & 99.85 & 0.15 \\
0.250 & 8250.7 & 99.90 & 0.10 \\
0.125 & 8251.6 & 99.91 & 0.09 \\
0.075 & 8254.9 & 99.95 & 0.05 \\
\hline
\end{tabular}

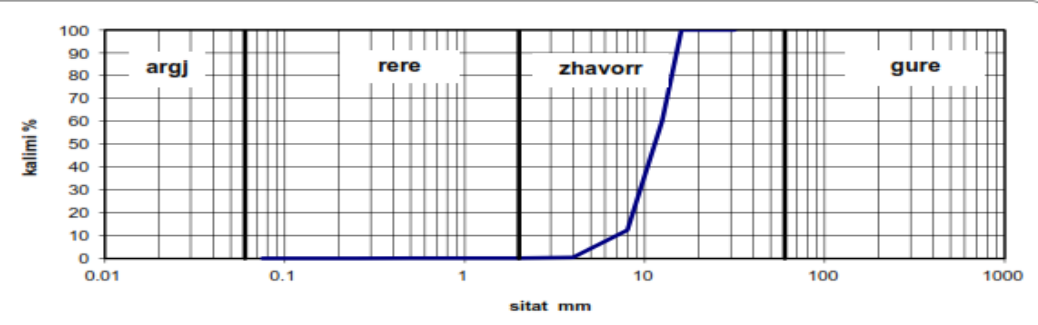

Figure 3: a) Coarse and b) fine aggregates PSD analysis river 
Rere e lare lumi $00 / 08 \mathrm{~mm}$

Test Method :

\section{Prrol I thate}

EN 1097-6-2000( piknometer method )

\begin{tabular}{|c|c|c|c|c|}
\hline $\mathrm{Nr}$ & Pershkrimi & njesia & \multicolumn{2}{|c|}{ kampioni } \\
\hline 1 & Madhesia e agregatit & $\mathrm{mm}$ & $0-8$ & $0-8$ \\
\hline 2 & Temperatura & ${ }^{\circ} \mathrm{C}$ & 20 & 20 \\
\hline 3 & Densiteti I ujit & $\mathrm{g} / \mathrm{cm} 3$ & 0.9981 & 0.9981 \\
\hline 4 & Pesha e kampionit te thate & $\mathrm{g}$ & 50.41 & 50.24 \\
\hline 5 & Pyknometer $\mathrm{No}(250 \mathrm{ml})$ & $\mathrm{ml}$ & 2 & 5 \\
\hline 6 & Pesha e piknometrit & $\mathrm{g}$ & 150.21 & 163.67 \\
\hline 7 & Pesha e piknometrit + uje & $\mathrm{g}$ & 466.72 & 480.08 \\
\hline 8 & Pesha e piknometrit + agregate & $\mathrm{g}$ & 200.62 & 213.91 \\
\hline 9 & Pesha e piknometrit + agregate+ uje & $\mathrm{g}$ & 498.73 & 512.21 \\
\hline 10 & Volumi I piknometrit & $\mathrm{cm} 3$ & 317.11 & 317.01 \\
\hline 11 & Pesha e kampionit satured & $\mathrm{g}$ & 51.31 & 50.99 \\
\hline 12 & Absorbimi I agregattit & $\%$ & 1.785 & 1.493 \\
\hline 13 & Mesatarja e absorbimit & $\%$ & \multicolumn{2}{|c|}{1.639} \\
\hline 14 & Pesha spesifike per cdo kampion & $\mathrm{g} / \mathrm{cm} 3$ & 2.612 & 2.664 \\
\hline 15 & Mesatarja e peshes Specifike & $\mathrm{g} / \mathrm{cm} 3$ & \multicolumn{2}{|c|}{2.638} \\
\hline
\end{tabular}

Figure 4: a) Coarse and b) fine aggregates PSD analysis river
Kampioni
Karriera
Granil i thyer lumi 06/12,5 mm
Test Method
Prrol I thate
EN 1097-6-2000( piknometer method )

\begin{tabular}{|c|c|c|c|c|}
\hline $\mathrm{Nr}$ & Pershkrimi & njesia & \multicolumn{2}{|c|}{ kampioni } \\
\hline 1 & Madhesia e agregatit & $\mathrm{mm}$ & $=06-12,5$ & "06-12,5 \\
\hline 2 & Temperatura & ${ }^{\circ} \mathrm{C}$ & 20 & 20 \\
\hline 3 & Densiteti I ujit & $\mathrm{g} / \mathrm{cm} 3$ & 0.9981 & 0.9981 \\
\hline 4 & Pesha e kampionit te thate & $\mathrm{g}$ & 100.12 & 100.21 \\
\hline 5 & Pyknometer $\mathrm{No}(500 \mathrm{ml})$ & $\mathrm{ml}$ & 6 & 7 \\
\hline 6 & Pesha e piknometrit & $\mathrm{g}$ & 202.93 & 208.71 \\
\hline 7 & Pesha e piknometrit + uje & $\mathrm{g}$ & 794.71 & 797.58 \\
\hline 8 & Pesha e piknometrit + agregate & $\mathrm{g}$ & 303.05 & 308.92 \\
\hline 9 & Pesha e piknometrit + agregate+ uje & $\mathrm{g}$ & 858.14 & 861.14 \\
\hline 10 & Volumi I piknometrit & $\mathrm{cm} 3$ & 592.89 & 589.98 \\
\hline 11 & Pesha e kampionit satured & $\mathrm{g}$ & 100.52 & 100.63 \\
\hline 12 & Absorbimi I agregattit & $\%$ & 0.400 & 0.419 \\
\hline 13 & Mesatarja e absorbimit & $\%$ & \multicolumn{2}{|c|}{0.409} \\
\hline 14 & Pesha spesifike per cdo kampion & $\mathrm{g} / \mathrm{cm} 3$ & 2.699 & 2.703 \\
\hline 15 & Mesatarja e peshes Specifike & $\mathrm{g} / \mathrm{cm} 3$ & \multicolumn{2}{|c|}{2.701} \\
\hline
\end{tabular}

Figure 5: a) Coarse and b) fine aggregates PSD analysis river 


\begin{tabular}{|c|c|c||c}
\hline sieve mm & weight g & retained \% & passing \% \\
\hline 31.5 & 0.0 & 0.00 & 100.00 \\
25 & 0.0 & 0.00 & 100.00 \\
20 & 0.0 & 0.00 & 100.00 \\
16 & 0.0 & 0.00 & 100.00 \\
12.5 & 0.0 & 0.00 & 100.00 \\
8 & 0.0 & 0.00 & 100.00 \\
4 & 100.0 & 7.02 & 92.98 \\
2 & 583.0 & 40.91 & 59.09 \\
1 & 942.0 & 66.11 & 33.89 \\
0.50 & 1191.0 & 83.58 & 16.42 \\
0.250 & 1337.0 & 93.82 & 6.18 \\
0.125 & 1393.0 & 97.75 & 2.25 \\
0.075 & 1406.0 & 98.67 & 1.33 \\
\hline Initial Weight gr & & & \\
\hline
\end{tabular}

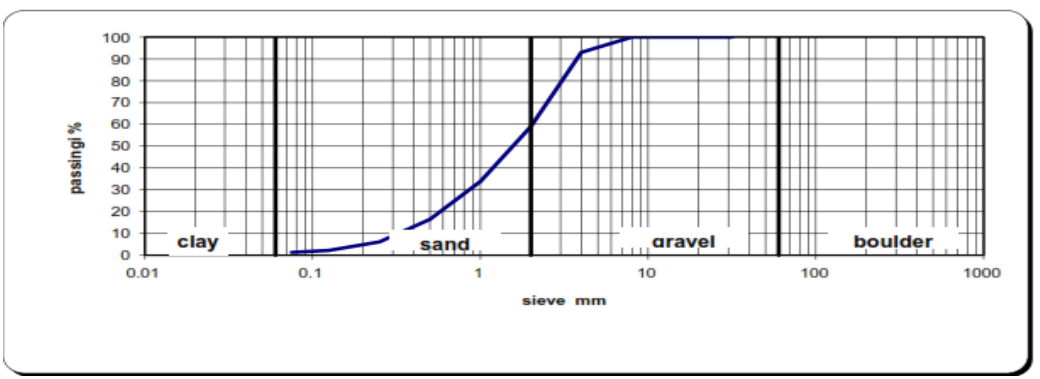

Figure 6: a) Coarse and b) fine aggregates PSD analysis river

\begin{tabular}{|c|c|c|c|}
\hline Test Method: & EN 933-01 & & \\
\hline sieve mm & weight g & retained \% & passing $\%$ \\
\hline 31.5 & 0.0 & 0.00 & 100.00 \\
\hline 25 & 0.0 & 0.00 & 100.00 \\
\hline 20 & 0.0 & 0.00 & 100.00 \\
\hline 16 & 0.0 & 0.00 & 100.00 \\
\hline 12.5 & 15.0 & 0.61 & 99.39 \\
\hline 8 & 1337.0 & 54.53 & 45.47 \\
\hline 4 & 2442.0 & 99.59 & 0.41 \\
\hline 2 & 2448.0 & 99.84 & 0.16 \\
\hline 1 & 2449.0 & 99.88 & 0.12 \\
\hline 0.50 & 2450.0 & 99.92 & 0.08 \\
\hline 0.250 & 2450.0 & 99.92 & 0.08 \\
\hline 0.125 & 2450.0 & 99.92 & 0.08 \\
\hline 0.075 & 2450.0 & 99.92 & 0.08 \\
\hline Initial Weight & & 2452 & \\
\hline
\end{tabular}

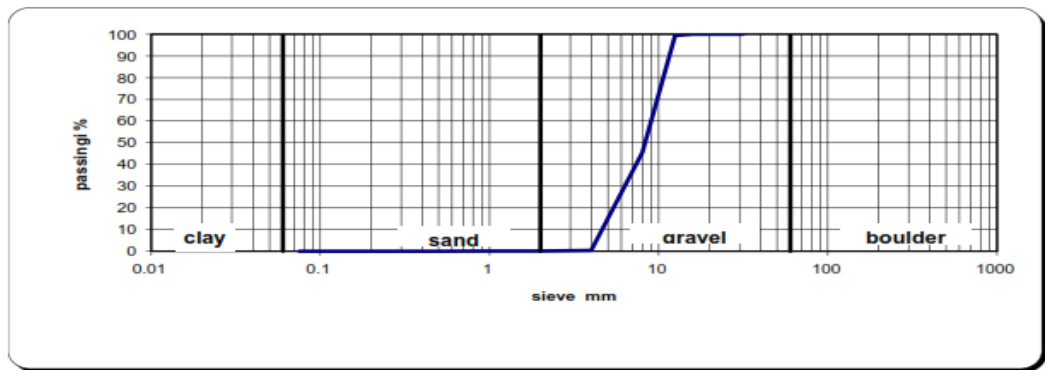

Figure 7: a) Coarse and b) fine aggregates PSD analysis river 


\begin{tabular}{|c|c|c||c|}
\hline sieve mm & weight g & retained \% & passing \% \\
\hline 31.5 & 0.0 & 0.00 & 100.00 \\
25 & 117.0 & 1.71 & 98.29 \\
20 & 2124.0 & 31.02 & 68.98 \\
16 & 4466.0 & 65.22 & 34.78 \\
12.5 & 6494.0 & 94.83 & 5.17 \\
8 & 6843.0 & 99.93 & 0.07 \\
4 & 6843.0 & 99.93 & 0.07 \\
2 & 6844.0 & 99.94 & 0.06 \\
1 & 6844.0 & 99.94 & 0.06 \\
0.50 & 6845.0 & 99.96 & 0.04 \\
0.250 & 6845.0 & 99.96 & 0.04 \\
0.125 & 6845.0 & 99.96 & 0.04 \\
0.075 & 6845.0 & 99.96 & 0.04 \\
\hline
\end{tabular}

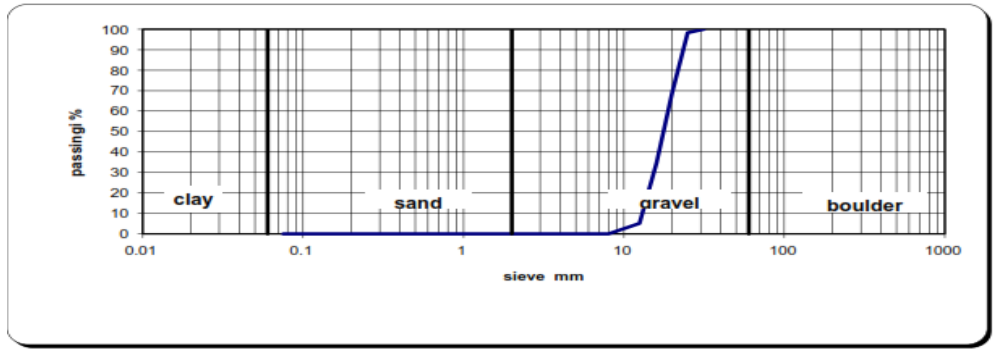

Figure 8: a) Coarse and b) fine aggregates PSD analysis river

Table 2.3.1: The aggregate chemical composition

\begin{tabular}{|l|l|l|l|l|}
\hline \begin{tabular}{l} 
Chemical $\begin{array}{l}\text { composition } \\
\text { aggregates }\end{array}$ \\
\cline { 2 - 5 }
\end{tabular} & $\mathrm{CaO}$ & $\mathrm{MgO}$ & $\mathrm{SiO}_{2}$ & $\mathrm{Fe}_{2} \mathrm{O}_{3}$ \\
\hline $\begin{array}{l}\text { Vega Fushe Kruje } \\
\text { (Mountain ) }\end{array}$ & 43.59 & 4.23 & 0.18 & 0.12 \\
\hline $\begin{array}{l}\text { Perroi i Thate } \\
\text { (Mat river) }\end{array}$ & 5.36 & 15.98 & 48.36 & 5.89 \\
\hline
\end{tabular}

Mount aggregates have been derived from carbonate rocks, with high content of limestone.

River aggregates are with originate volcanic and therefore have a high content of basalt.

\subsubsection{Water}

Potable tap water available production site was used for mixing and curing of concrete. The water is filtrate based on standard S Sh 2751:1987.

Table 2.1.3.1: Chemical analysis of water used in mix design 


\begin{tabular}{|c|l|c|c|c|}
\hline No. & \multicolumn{1}{|c|}{ Characte ris tics } & Units & Test results & $\begin{array}{c}\text { Standard limit } \\
\text { EN 1008 }\end{array}$ \\
\hline 1 & Water resource & & Well water & - \\
\hline 2 & Colour & & Transparent & - \\
\hline 3 & Odour & & None & - \\
\hline 4 & Water density @ 190 C & $\mathrm{kg} / \mathrm{l}$ & 1.0082 & 0.9982 \\
\hline 5 & Total hardness $(\mathrm{CaCO} 3)$ & $\mathrm{mg} / \mathrm{l}$ & 2.91 & - \\
\hline 6 & Total dissolved solids at $180^{\circ} \mathrm{C}$ & $\mathrm{mg} / \mathrm{l}$ & 3.82 & $\leq 4$ \\
\hline 7 & pH value & & 7.61 & $\leq 4$ \\
\hline 8 & Chloride content $\mathrm{Cl}-$ & $\mathrm{mg} / \mathrm{l}$ & 1241 & $\leq 1000$ \\
\hline 9 & Sulphate content SO4- & $\mathrm{mg} / \mathrm{l}$ & 4996 & $\leq 2000$ \\
\hline 10 & Salts content & $\mathrm{mg} / \mathrm{l}$ & 0.02 & $\leq 100$ \\
\hline
\end{tabular}

\subsubsection{Concrete admixtures}

Additives used in this project are; Chryso-Fluid Premia 180(superplasticizer) and in quantities $3 \mathrm{l} / \mathrm{m} 3$ concrete. Additives were used to produce concrete class $\mathrm{C} 35 / 45 \mathrm{MPa}$ and the result was decreasing the amount of water. The effect of using the lowest amount of water is increasing the durability and resistance of concrete.

\section{$2.2 \quad$ Methodology}

\subsubsection{Durable concrete mix design}

Mix design is a process of selecting suitable ingredients for concrete and determining their proportions which would produce, as economically as possible, a concrete that satisfies the Orion project requirements.

All mix designs data for durable concrete used in our project are represented in Table 2.2.1.1. In present study durable concrete class C35/45 was produced with river raw material. All mix designs are formulated based on specifications of EN 206-1:2003 standard. Date 10.10.2013

Table 2.2.1.1: Mix design of concrete from Kruja mountain

\begin{tabular}{|l|l|l|l|}
\hline No. & Ingredients & Units $/ \mathrm{m}^{3}$ & Quantity \\
\hline 1 & Crashed sand 0-04 mm & $\mathrm{kg}$ & 895 \\
\hline 2 & Crashed river gravel 5-10 mm & $\mathrm{kg}$ & 298 \\
\hline 3 & Crashed river gravel 10-25mm & $\mathrm{kg}$ & 698 \\
\hline 4 & Cement CEM I 45.2 R/A-LL & $\mathrm{kg}$ & 370 \\
\hline 5 & $\begin{array}{l}\text { Additive Chryso-Fluid Premia 180 (superplasticizer) } \\
\text { Reduction. 15\%; Dosage 0.8 lit/100 kg cement) }\end{array}$ & $\mathrm{lit} / \mathrm{m}^{3}$ & 3.32 \\
\hline 6 & Well water & lit & 158 \\
\hline 1 & w/c ratio & - & 0.4 \\
\hline 2 & Density & $\mathrm{kg}$ & 2422 \\
\hline 3 & Temperature of fresh concrete & ${ }^{\circ} \mathrm{C}$ & 19 \\
\hline 4 & Slump & & $\mathrm{S} 4$ \\
\hline
\end{tabular}

Date 27.11.2013

Table 2.2.1.1: Mix design of concrete from Mat river 


\begin{tabular}{|l|l|l|l|}
\hline No. & Ingredients & Units $/ \mathrm{m}^{3}$ & Quantity \\
\hline 1 & Natural river sand 0-04 mm & $\mathrm{kg}$ & 915 \\
\hline 2 & Natural river gravel $5-10 \mathrm{~mm}$ & $\mathrm{~kg}$ & 294 \\
\hline 3 & Natural river gravel 10-25mm & $\mathrm{kg}$ & 695 \\
\hline 4 & Cement CEM I 45.2 R/A-LL & $\mathrm{kg}$ & 380 \\
\hline 5 & $\begin{array}{l}\text { Additive Chryso-Fluid Premia 180 (superplasticizer) } \\
\text { Reduction. 15\%; Dosage 0.8 lit/100 kg cement) }\end{array}$ & $\mathrm{lit} / \mathrm{m}^{3}$ & 151 \\
\hline 6 & Well water & $\mathrm{lit}$ & 3.56 \\
\hline 1 & W/c ratio & - & 0.4 \\
\hline 2 & Density & $\mathrm{kg}$ & 2440 \\
\hline 3 & Temperature of fresh concrete & ${ }^{\circ} \mathrm{C}$ & 19 \\
\hline 4 & Slump & & $\mathrm{S} 4$ \\
\hline
\end{tabular}

The compressive strength of concrete is considered as the index of its quality. Therefore the mix designs are generally carried out for a particular compressive strength of concrete with adequate workability so that the fresh concrete can be properly mixed, placed and compacted.

After 28 days period of curing, the specimens were taken out of the curing tank and there were tested besides measuring the fresh properties (workability, air content and concrete temperature); following tests such as permeability of concrete cubes and chlorides contents are measured.

\section{RESULTS \& TABLES}

\subsection{Compressive strength of concrete cubes}

Compressive strength, of mixes was determined at various ages as per EN 12390-3:1999 and EN 12390-5:1999 are given in table 3.1. Cube Compressive strength at the age 7 and 28 days. After casting the specimens were covered with sheets to minimize the moisture loss from them. Specimens were demoulded after 24-hours and then cured in water at approximately room temperature till testing. Compressive strength tests for cubes were carried out at 28 days. All the specimens were tested in an automated compressive strength machine shown in Figure 3.1:

Table 3.1: Test results obtained from durable concrete produced with Mat river materials

\begin{tabular}{|l|l|l|l|l|l|l|}
\hline \multirow{3}{*}{ No. } & \multicolumn{2}{|l|}{$\begin{array}{l}\text { Normal water curing condition } \\
\text { (Kruja Mountin crashed aggregates) }\end{array}$} & \multicolumn{2}{l|}{$\begin{array}{l}\text { Normal water curing condition } \\
\text { (Mat River aggregates) }\end{array}$} \\
\cline { 2 - 8 } & $\begin{array}{l}\text { Compressive } \\
\text { strength }\end{array}$ & $\begin{array}{l}\text { Water depth } \\
\text { penetration }\end{array}$ & day & $\begin{array}{l}\text { Compressive } \\
\text { strength }\end{array}$ & $\begin{array}{l}\text { Water depth } \\
\text { penetration }\end{array}$ & \\
\hline 1 & 44.180 & 22.13 & 28 & 43.012 & 11.2 & 28 \\
\hline 2 & 40.123 & 19.25 & 28 & 46.338 & 10.8 & 28 \\
\hline 3 & 42.156 & 14.35 & 28 & 42.230 & 16.2 & 28 \\
\hline 4 & 46.337 & 19.4 & 90 & 47.894 & 9.2 & 90 \\
\hline 5 & 47.250 & 20.5 & 90 & 48.154 & 9.4 & 90 \\
\hline 6 & 46.510 & 24.1 & 90 & 48.112 & 7.6 & 90 \\
\hline
\end{tabular}

Table 3.2: Test results obtained from durable concrete produced with Romanat materials

\section{GRAFIKE}




\subsection{Durability of concrete}

The durability of concrete depends largely on the movement of water enters and moves through it. Permeability is a measure of flow of water under pressure in a saturated porous medium while Sorptivity is materials ability to absorb and transmit water through it by capillary suction. The porous structure of concrete is intimately related with its permeability. A low water/cement ratio results in concrete structures which are less permeable because they are characterized by having small pores which are not interconnected. The water penetration under pressure test is a standard test procedure (EN 12390-8).
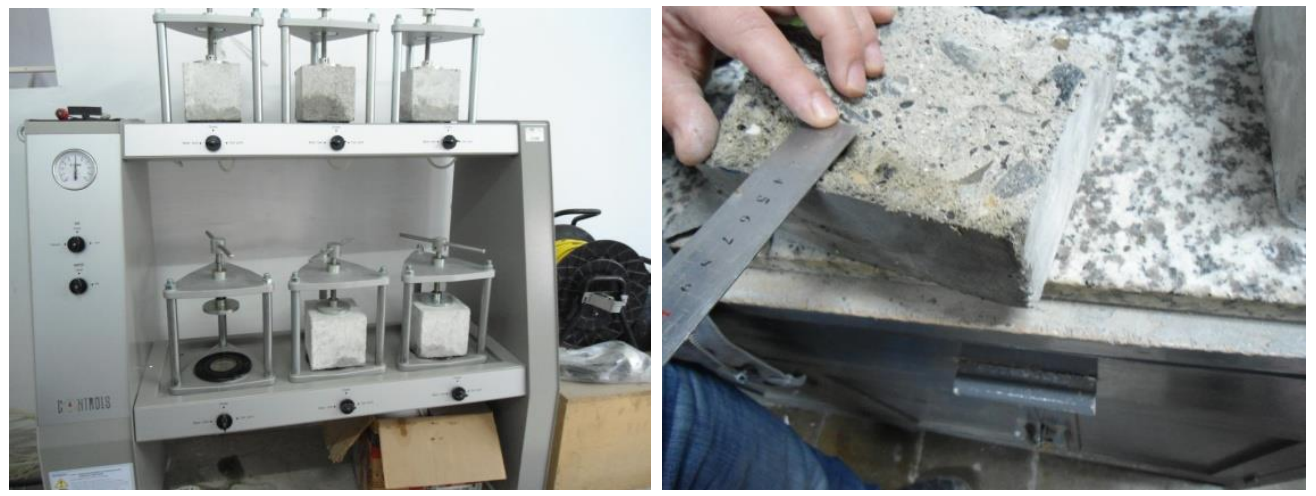

Figure 3.2.1: Images of water penetration

\section{CONCLUSIONS}

Production and use of durable concrete is critical to increasing lifespan reinforced concrete structures.

Durable concrete mechanical resistance also depends on the mineralogical composition of component aggregates.

Broken Mountain aggregates, which have a high percentage of limestone, give us a reziztence concrete with almost the same as the aggregate of the river, but having a large water permeability. This is because using a greater quantity of water. They are more economical in the use of cement.

River Aggregates, especially when they have high basalt backgrounds, are more compressed, give us concrete with high resistance, with low water permeability.

\section{ACKNOWLEDGMENTS}

I would like to thank all those people who have been involved directly or indirectly with my research work.

I appriciate the valuable support of my friends and colleagues, during the implementation of this research, including construction company, concrete production site company, the additives supply company, testing laboratories.

\section{REFERENCES}

[1] A.L.T.E.A report-Study of geological and engineering conditions of the building height 7-8-10 floors with one floor underground at the roadside "Deshmoret" in Durres. Pg 16-20.

[2] GeoSeis-IT Consulting report-Study of geological and engineering conditions of the building height 7-8-10 floors with one floor underground at the roadside "Deshmoret" in Durres. Pg 16-20.

[3] EN 206-1:2004 Concrete specification, performance, production and conformity. pg

[4]Traeger PA. Evaluation of the constructive use of foundry wastes in highway construction. MS thesis, The University of Wisconsin- Madison, Madison, Wisconsin, 1987.

[5]I.Struct.E/ICE Joint Committee, 1985. Manual for the Design of Reinforced Concrete Building Structures, Institution of Structural Engineers, London

\section{[6] Integral Capillary System Concrete Waterproofing- Foundation Structure- Foundation from Penetron}


[7] Edited by C.W.Yu and John W. Bull : " Durability of Materials and Structures in Building and Civil Engineering" book Michael S. Mamlouk and John P. Zaniewski : "Materials for Civil and Construction Engineers

[8] M. Collepardi, Admixtures used to enhance placing characteristics of concrete, Cement-Concrete Compose 20 (1998) 103-112.

[9] Eurocod 2: Cement structures design. Generally rules and houses rules.

[10] M. Collepardi, L.Coppola, Cement Italian Industry 665(1992).

[11] Significance of Tests and Properties of Concrete and Concrete-Making Materials (STP169D) (LT205)

[12] Richardson M., "Fundamentals of durable reinforced concrete", Modern concrete technology 11, series editors, pp. $51-101$

[12] Arum, C., and Udoh, I., 2005." Effect of dust inclusion in aggregate on the compressive strength of concrete", Journal of Science, Engineering and Technology, Vol.12 No. 2, Chyke-Cee, Enugu. pp. 6170-6184.

[13] Raheem, A.A. and Aderounmu, O.M., 2002. "The effect of aggregate sizes on the strength of concrete", Journal of Science, Engineering and Technology, Vol.9 No. 2, Chyke-Cee, Enugu. pp. 4041-4051.

[14] C. Arum and A.O. Olotuah, "Making of strong and durable concrete", Received February 2006 and accepted may 2006 in Emirates Journal for Engineering Research, 11(1),25-31(2006)

[15] S SH EN 13139: 2002

[16] UA_2008_22_aditional for concrete, conform Standard SK EN 206-1, first part

[17] Edited by John Newman \& Ban Seng Choo, "Advanced Concrete Technology" Part 2,Concrete Properties, pp. 8/3$8 / 9$. 